The Polish Journal of the Arts and Culture. New Series 5

(1/2017): 67-87 [ARTICLE]

DOI: $10.4467 / 24506249 \mathrm{PJ} .17 .004 .6811$

\title{
Visual Propaganda in the Democratic Republic of Afghanistan - Part 2. Leading Role of the Party
}

\author{
Mateusz M. KŁAGISZ
}

\begin{abstract}
In this article, a single poster of the People's Democratic Party of Afghanistan is discussed. The starting point for the project is the statement that persuasion is more effective than compulsion and the fact that the Afghan communists did not find any formula to start an effective dialogue with their society. The primary question for the article is: what kind of communication, and what sort of themes and motifs played a significant role in conveying revolutionary ideology aimed at a society where a majority, with political potential, could not read or write?
\end{abstract}

Keywords: Party, masses, leading role, unity, cooperation

Dr. Mateusz M. KŁAGISz is an assistant professor at the Department of Iranian Studies at the Jagiellonian University in Kraków. His main area of research on Afghanistan includes the question of modernisation and regression in twentieth-century Afghanistan, especially in the communist period (1978-1992).

E-MAIL: mateusz.klagisz@uj.edu.pl 
Our party is our school / And our laughter / We are its guard / We follow its path / (...) / We are scouts / And we are equal / If you fight with the enemy / You are the scouts' friend ${ }^{1}$

The article, as a continuation of a text published in $2015^{2}$, is part of a research project on the propaganda employed by the would-be Leninist government represented by the People's Democratic Party of Afghanistan (hereafter: PDPA) ${ }^{3}$. The language as well as the medium of communication applied by the regime while addressing its audience - i.e. the Afghan society - are important for two reasons: firstly, because the authorities are granted confidence by the citizens who at the same time have the right to prolong (or not) their credit of trust depending on the current political, social and economic situation. To stay in power, the authorities use phraseology that is clear for the audience, convincing them of their own version of politics and vision of reality ${ }^{4}$

A basic step in accomplishing this transformation is to gain an absolute dominance over the sources of information available to the invaded people, thereby regulating what they read, what they hear and, over a time, how they view their history and themselves ${ }^{5}$.

Such a conclusion moves us towards the second reason - the clarity and obscurity of the message. The majority of the Islamic elites, confronting the need for modernisation, remained loyal to their religion, its ideas, values and language, but there was a small group that praised Western achievements.

${ }^{1}$ Khoshe-ye khorshid. Gozine-ye she'r-e kudak [Rays of sunshine. Selections from poetry for children], Kabol 1363AP/1984-5, p. 24 [trans. MMK].

2 M. M. Kłagisz, Visual Propaganda in the Democratic Republic of Afghanistan - Preliminary Report, "The Polish Journal of the Arts and Culture" 2015, no. 14 (2), pp. 101-122.

3 I use the expression "would-be Leninist" following O. Roy's statement: "One can wonder if Afghan communists (who always refrained from referring to communism) are truly communists" (O. Roy, The Origins of the Afghan Communist party, "Central Asian Survey" 1988, no. 7 (2-3), p. 52).

4 A. Kampka, Retoryka jako manifestacja i uprawomocnienie władzy [in:] Między znaczeniem a dziataniem. Retoryka $i$ wtadza, ed. A. Kampka, Warszawa 2012, pp. 19 ff.

5 A. Rasul Amin, A General Reflection on the Stealthy Sovietisation of Afghanistan, "Central Asian Survey" 1984, no. 3 (1), p. 47. 
They created their own tongue that was largely unknown to most of their (il)literate compatriots. H. Enayat's words that:

The breakdown of the cultural integration of traditional society was thus reflected in a linguistic rift, which has been one of the chief obstacles to a coherent, sustained and fruitful debate among Muslims of all classes and ages over their social and political problems ${ }^{6}$,

should be kept in mind, while reading this text based on a combined philological-and-anthropological approach proposed by R. Barthes in his article Rhetoric of the Image ${ }^{7}$.

R. Barthes, posing such questions as "How does meaning get into the image? Where does it end? And if it ends, what is there beyond?" , considered not whether the image could function as a conveyor of meaning, but how it would actually do that. In his opinion, the picture needs to constitute its own language. In the context of politics, such tools of rhetoric used to manifest or legitimatise authority should be understood as a perlocutionary act affecting the addressee 9 . In the context of Afghanistan, the phenomenon of the Bildkultur - introduced in the Preliminary Report - is inevitable. The Bildkultur is an open-access, culturally-constructed semantic system made up of pictorial signs used for mass (re-)creation, (re-)transfer and (re-)storage of common memory on the same (or similar) terms as the high or popular Afghan poetry has been doing for centuries. R. Barthes wrote that: " $[t]$ here are those who think that the image is an extremely rudimentary system in comparison with language and those who think that signification cannot exhaust the image's ineffable richness"10. Therefore, the picture plays a more complex role than merely aesthetic ${ }^{11}$ and embraces, inter alia, the takbir sentence Allahu akbar

6 H. Enayat, Modern Islamic Political Thought, Austin 1982, p. 3.

7 Cf. also: E. Bauer, Sprachlicher Wandel als Ergebnis politisch motivierter Sprachlenkung: neuere Entwicklungen im Pashto Afghanistans, [in:] Proceedings of the Second European Conference of Iranian Studies held in Bamberg, 3oth September to 4 th October 1991, by the Societas Iranologica Europeae, eds. B. G. Fragner et al., Rome 1995, pp. 53-63.

8 R. Barthes, Rhetoric of the Image, [in:] Barthes R., Image - Music - Text, trans. S. Heath, New York 1977, p. 32.

9 J. L. Austin, Mówienie i poznawanie. Rozprawy i wykłady filozoficzne, przeł. B. Chwedeńczuk, Warszawa 1993, p. 317.

${ }^{10}$ R. Barthes, op. cit., p. 32.

${ }^{11}$ P. Chelkowski, H. Dabashi, Staging a Revolution: The Art of Persuasion in the Islamic Republic 
"God is the greatest", the basmala one b-ismi-llahi-r-rahmani-r-rahimi "In the name of God, the Most Gracious, the Most Merciful", or the name of the Prophet Muhammad that can be "read" in public by illiterates too because they recognise their complex calligraphic structures rather than particular letters ${ }^{12}$. Taking into account the traditional Islamic approach towards the picture, one should emphasise here that in Sunni Afghanistan, the Bildkultur, represented by Bollywood/Lollywood posters, religious pictures, naïve paintings on trucks, in tea-houses, school books and bills, flyers, hoardings, photography and television is, contrary to its neighbours Iran and Pakistan, still in stadium nascendi ${ }^{13}$.

An example of the Afghan Bildkultur is a mural photographed by P. Centlivres and M. Centlivres-Demont in October 1990 in Kabul (see: figure 1). One can see a girl giving water to an apparently tired solder sitting on the ground. The girl wears a chador tightly wrapped around her figure. The authors suggested that such a piece of cloth refers to the Muslim tradition rather than to the leftist ideology of the Kabul regime, but we should recall here another pro-government poster from the mid 1980s in which a woman, encouraging young men to join the national army, wears a chador too.

This dress may somehow refer to M. Najibullah's political return toward "Afghanicity" understood as traditionalism as well as an abandonment of the previously used socialist stylistics. In a booklet published on the occasion of the 1oth Congress of the PDPA, one can read that due to historical and cultural peculiarities it is impossible to build socialism in Afghanistan, and that the PDPA itself must be of a Marxist-Leninist character(!):

Question 2: Is the PDPA a Marxist-Leninist party?

Answer: The PDPA frankly announced that there were no conditions in the country to build socialism. (...) On the contrary, the PDPA claimed that it adopted methods to solve problems

of Iran, New York 1999, p. 34; J. S. Elias, Aisha's Cushion. Religious Art, Perception, and Practice in Islam, Cambridge MA-London 2012, p. 18 [useful references].

${ }^{12}$ J. S. Elias, op. cit., pp. 236-263.

${ }^{13}$ On Afghan visual arts, e.g.: M. Centlivres-Demont, Popular Art in Afghanistan. Paintings on Trucks, Mosques and Tea-Houses, trans. R. Charleston, Graz 1976; P. Centlivres, M. CentlivresDemont, Et si on parlait de l'Afghanistan. Terrains et textes 1964-198o, Paris 1988, pp. 95-117; L. Dzięgiel, J. Pstrusińska, Rysunkowe echa egzotycznej wojny, "Arcana” 2001, no. 41 (5), pp. 167-172; M. Vogel, Roter Teufel - mächtiger muğahid. Widerstandsbilder im sowjetischafghanischen Krieg 1979-1989, Wien-Köln-Weimar 2008. 
according to the national reconciliation philosophy and fought to realise them. Thus the PDPA cannot be a Marxist-Leninist party $^{14}$.

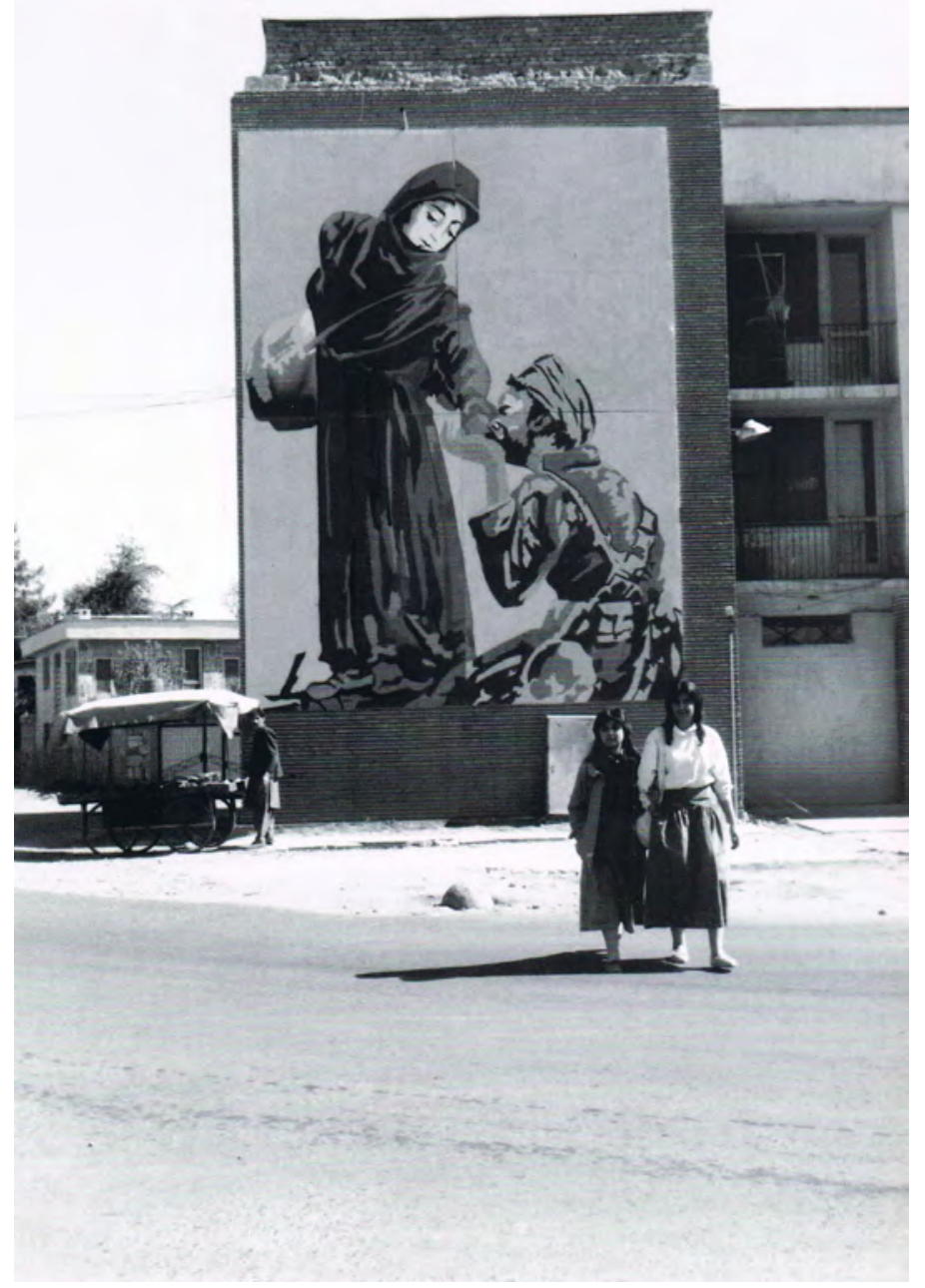

Fig. 1

The pictorial semantic system of the Bildkultur means that the ideological ambiguity of the Kabul regime in the 1980s/1990s is reflected in the figure of the solder too. Does he wear a képi (a headdress typical for the state army) or

${ }_{14} 30$ so'al va 30 javab dar bare-ye H.D.Kh.A. va siyasat-e an [3o questions and 30 answers about the PDPA and its politics], Kabol 1369AP/1990-1, p. 2 [trans. MMK]. 
a turban (headgear worn by guerrillas)? Additionally, the painting suggests that the official system, where women have their place, is less warlike and more charitable ${ }^{15}$. Afghan charity and benevolence appear in the figure of the girl symbolising the homeland (as well as the Kabul-based government), although in common Afghan imagination the homeland is perceived as masculine rather than feminine; is this a Soviet import? ${ }^{16}$

As in the Preliminary Report, the core element of the paper is a single socialist realistic poster published in a Moscow-printed album Afganistan, revolucya prodolzhayecya. This time the matter of concern was the creation of a myth of an all-Afghan proletarian uprising against M. D. Khan's régime and its transferral to placards and postage stamps. This time a poster dedicated to the leadership role of the PDPA will be discussed because: "[ $t$ ]he leading role of the party is a prerequisite for seizure of power and ruling by the working class while building socialism" ${ }^{17}$. Considering the nature of socialist realism accompanied by the acceptance of the artificially created world that is validated later by the stamp of normality, the poster tries to convince us that the others have accepted the truth about the PDPA's leadership before us:

A newcomer climbed yesterday onto the refractory rock

in fear of darkness and despair.

His every step makes time bright,

His every breath is a fervour of triumph,

He is able to act even if we cannot,

He knows what we do not.

Who is he?

A newly-found mystic,

Some-one who opens [us] new places to stay,

${ }_{15}$ P. Centlivres, M. Centrlivres-Demont M., Portraits d'Afghanistan, Paris 2002, p. 210.

${ }^{16}$ Cf. Also: M.-O. Terrenoire, Guerre d'Afghanistan - Images de femmes, "Central Asian Survey" 1987, no. 6( 3), pp. 77-102. One can recall here Nazo Tokhay (17th/18th c.) - a Pashtun poet and warrior who later became the "Mother of Afghan Nation" (M. Hotak bin Davud, Pata Khazana, Kabol 1339AP/1960-1, pp. 176-179), as well as Malalay who led Afghan fighters against the British troops at the Battle of Maiwand on 27th July 1880. One should also consider here Bharat Mata - the national personification of India presented as a mother goddess (M. Gaenszle, J. Gengnagel, Visualizing Space in Banaras. Images, Maps, and the Practice of Representation, Wiesbaden 2006, pp. 177 ff.).

${ }^{17}$ Partia - państwo - społeczeństwo, ed. R. Dudek, Z. Siembirowicz, Warszawa 1978, p. 55. 
A lover that does not fear death.

Someone who has just started but leads others.

In yesterday's deadly chill

he kindled tomorrow's temple of fire,

(...)

We have lost our way in darkness,

Hey, finder of illuminated paths

Pay attention to the lost caravan

As it is fine and you know ${ }^{18}$.

The fragility of its social leading role became significant shortly after the PDPA, internally divided between two antagonised Khalq and Parcham factions, seized power during a one-day military coup d'état on 27th April 1978. No-one could expect that the communists would so quickly be at each other's throats and so easily antagonise their own society by manifesting their lack of awareness of the dynamics characteristic of the Afghan political landscape. Popular local uprisings against the regime started in the summer of 1978, proving an unwritten law that being too proud and too confident does not guarantee success ${ }^{19}$. At the beginning of the 1980s, the new Central Committee of the PDPA, established thanks to the Soviet military intervention in December 1979, tried initially to broaden its social base to counteract guerrilla activity and to support its own government but failed in the end. Facing, inter alia, lasting political-and-military upheavals B. Karmal - the contemporaneous General Secretary of the CC of the PDPA and Chairman of the Presidium of the Revolutionary Council - referred to a typical MarxistLeninist form of rule promoted by his Soviet advisers who even wrote his speeches. Since 1981 a few umbrella organisations supporting the PDPA government were established to imitate political pluralism. Their common purpose was to mobilise non-party supporters and to carry party decisions to the public, as well as to demonstrate closeness and unity between both the PDPA and the society, because:

The leading position and role of the communist party in the system of political organisation and in the system of a socialist society finds expression in its creative inspirational and

${ }^{18}$ S. Layeq, Samt-e roushan-e jaddaha [The bright side of the roads], Kabol 1363AP/1984-5, pp. 1-2 [trans. MMK].

${ }^{19}$ T. Barfield, Afghanistan. A Cultural and Political History, Princeton-Oxford 2010, p. 164. 
programmatic activities towards the socialistic state allied with political clubs, trade unions, youth and other social organisations $^{20}$.

This manœuvre was also necessary by virtue of some specific features of Afghan politics where: "[ $t]$ he periodic and often-rapid collapses of state power (...) had their roots in the persistence of violence at the top of the system" ${ }^{21}$ and "(...) that after the fall of the monarchy in 1973, each succeeding regime had a weaker claim to political legitimacy than had its predecessor in the eyes of ordinary Afghans"22. Under the circumstances, the PDPA was compelled to create its proletarian myth ex nihilo and to sell the society its right to rule, constantly referring to the party-masses union. One of the many ways to reach out to citizens so that they could become aware of the PDPA was a poster like this:

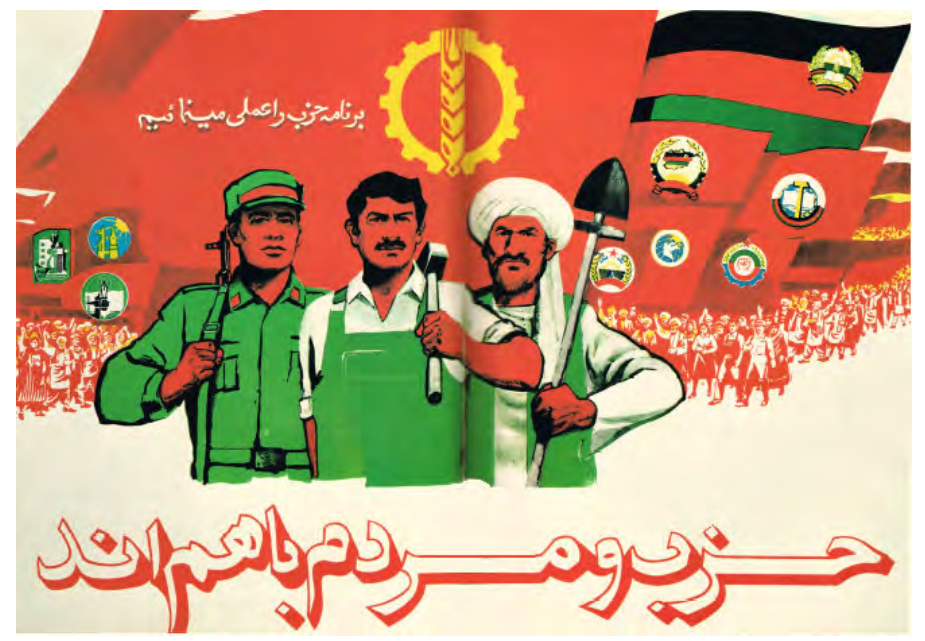

Fig. 2

Following R. Barthes' article, one can study this poster on three levels: (1) a linguistic message easily distinguishable from (2) a coded iconic one, and finally (3) a non-coded iconic message ${ }^{23}$.

The first kind of the message, of linguistic substance, appears on the poster twice - once as a turgid exclamation: Hezb va mardom ba ham-and

${ }^{20}$ Partia - państwo - społeczeństwo, op. cit., pp. 57-58.

${ }^{21}$ T. Barfield, op. cit., p. 164.

${ }^{22}$ Ibidem, pp. 164-165.

${ }^{23}$ R. Barthes, op. cit., p. 36. 
"The party and the people are together" and other as an ideological declaration: Barname-ye hezb-ra amali minama'im "We execute the programme of the party in practice". Although R. Barthes writes that the linguistic message appears somewhat before the two others ${ }^{24}$, one can dispute this assumption by raising the issue of illiterate addressees. To decipher the code of the message incorporated into the poster, one need to possess two sorts of skills knowledge of the script and command of the Dari language. In the case of the illiterate, a command of language is not enough to decode the message even if (s)he is a Dari native speaker unless the message is verbalised by someone else. If no-one can verbalise it, this part remains mute and must be expressed by the pictorial element. This means that there is a slight variation in reading the posters, because a literate person first caches the text while moving his/her attention towards the graphic, yet an illiterate ignores the text, focusing on the picture only ${ }^{25}$.

According to R. Barthes, the linguistic message can be consolidated into two closely related messages - denoted and connoted. It means that the noun hezb "party" does not only substitute the name of the PDPA, but furthermore via a sub-/semi-/un-/conscious reference to general ideas regarding its political programme it exposes the observer to additional value - that of Marxism-Leninism (even if B. Karmal tried to avoid the noun "socialism" in his speeches ${ }^{26}$ ) or rather of "Sovieticity" as the political awareness

${ }^{24}$ Ibidem, p. 33.

25 The literate addressee can see the image and read the words, while the illiterate one can only see the image. This means that the combination of the picture and the slogan operates on two levels. The first one is of a mixed visual-and-verbal character, while the second one is of a visual nature only (P. Chelkowski, H. Dabashi, op. cit., p. 42). Since the poster must grab the observer's attention to unveil its message and to make a long-lasting impression on him/her, its potency results primarily from clarity of its own language conveyed by the picture and only secondly by the word. This means that the poster makes use of the Bildkultur, i.e. such sets of symbols that are coherent, understandable and self-explanatory for everyone notwithstanding (il)literacy.

${ }^{26}$ The would-be Marxist-Leninist linchpin of the PDPA instigated attempts to adopt the figure of V. I. Ulyanov Lenin for local political proposes. On the 11 oth anniversary of his birthday a series of commemorative articles were published in the Haqiqat-e Enqelab-e Saur [Truth of the April Revolution] 03.02.1360AP / 23.04.1981, no. 101 (hereafter: HES; the official newspaper of the PDPA published between 1980-1990, later replaced by Payam [Message]; the similarity between its name and the title of the official newspaper of the Communist Party of the Soviet Union - Pravda [Truth], is significant). Readers learned about Lenin's life and work (Zendegi va asar-e Lenin [Lenin's live and works] (p. 3); Sima-ye Lenin dar ayine-ye zendegi-ye khosusi [Lenin's picture in the reflection of private life] (p. 4); Amuzesh-e Lenin- 
of many Afghans was constructed by the presence of the Red Army troops. The second significant element of the linguistic message is the noun mardom "people" referring to Afghan society. There is an organic link between both hezb and mardom as: "The social system characteristic for the socialism creates, because of its own nature, subjective and objective presumptions for integration of basic classes and layers of the whole nation" ${ }^{27}$. The question is if the usage of the noun mardom, instead of khalq "the people, the masses", tuda "the masses" or millat "nation", was caused by a (sub)conscious intention to play-down the socialist tone of the poster and intensify its general message, or not. While khalq or tuda refer to the proletariat directly, and millat as a "nation" (i.e. more than a "religious community") is somehow still a new concept in 2oth-century Afghanistan, mardom shall embrace all members of society such as the urban intelligentsia as well as the tribal aristocracy, because: "In the process of fulfilling the goals of socialism, the party must also gain the conscious support of the most active and having the social authority part of the workers and other groups of working people and the approval of the broad masses"28.

A. Kampka writers that words spoken in a certain place and at a given time have the strength to determine or validate authority and domination. The recipients' behaviour is also of a constitutive character because any declaration about possession of power would be meaningless without their nodding consent ${ }^{29}$. Consequently, "The party and the people are together" is not a simple statement but a dogmatic piece of hyperbole idealising the relations between both groups and suggesting that both hold the same position. Nonetheless, such equality is illusory because of the nature of the party as a proletarian avant-garde - i.e. a prerequisite for the worker-and-peasant administration: "The leading role of the party is a prerequisite for gaining power and its exercise by the working class in the period of construction of socialism"30. B. Karmal repeatedly said:

mash'al-e rahnama-ye razmandegan-e enqelabi [Lenin's teaching - a guiding torch of revolutionary fighters] (p. 4)), his relations with Afghanistan (Lenin va Afqanestan [Lenin and Afghanistan] (p. 1)) and could see a photography of Lenin while reading Pravda. The picture was complemented with a slogan - Lenin zist. Lenin me-ziyad. Lenin khahad zist, i.e. a Dari translation of a Soviet rallying cry based on an omnipresent refrain of V. V. Mayakovsky's poem Komsomolskaya [The Komsomol Song] "Lenin lived, Lenin lives, Lenin is to live forever".

${ }^{27}$ Partia - państwo - spoleczeństwo, op. cit., p. 92.

${ }^{28}$ Ibidem, p. 99.

${ }^{29}$ A. Kampka, op. cit., p. 20.

${ }^{30}$ Partia - państwo - społeczeństwo, op. cit., p. 55. 
Thanks to the victory of the Saur Revolution under the guidance of the PDPA for the first time in the history of [our] country political power represented by the workers, peasants and the rest of the working classes has been transferred to the PDPA [trans. and emphasised by $\mathrm{MMK}]^{31}$.

Our party takes responsibility for ensuring the welfare and felicity of the broad masses of Afghanistan. The PDPA arose from the masses [and] reflects the interests of the working classes as well as all progressive forces and realises its duties, serving the people and the homeland truly [trans. and emphasised by $\mathrm{MMK}]^{32}$.

What is more, the sentence "The party and the people are together" refers to a mutual contract signed by both sides sharing common targets. Without their cooperation it would be impossible to achieve them: "Unity of the party, the people and the military forces guarantees the victory of our revolution" 33 .

How can such an interpretation be justified? To answer the question, one should refer to a function of the word called by R. Barthes "anchorage" that creates self-limited frames in which the addressee places his/her understanding of the message, avoiding misleading individualisation and keeping the core meaning of the announcement. The anchorage function means that some elements of the message are highlighted and some others are "dark"lighted, i.e. rejected as unnecessary, unwanted, redundant or simply wrong. In the present case, the poster refers to the unity of the PDPA and the Afghan masses resulting from the proletarian roots of the former, to the cooperation of both collectivities resulting from common political and economic targets, as well as to the leading role of the PDPA perceived as the only power able to (re-)construct the masses by increasing their awareness ${ }^{34}$. The anchorage function means also that the poster, being ideologically concerned in, helps

${ }^{31}$ B. Karmal, Zenda bad ettehad-e tabaqe-ye kargar, dehqanan va hame-ye zahmatkashan-e keshvar-e ma! [Viva the unity of the classes of the workers and peasants and all the proletarians of our country!], [in:] B. Karmal, Dar rah-e tahkim-e hakmiyat-e khalq. Majmu'e-ye bayahiyaha va neveshtaha (1358-1359) [Towards the strengthening of mass leadership. A collection of speeches and texts (1358-1359)], Kabol 1362AP/1983-4, p. 309.

${ }^{32}$ Ibidem, p. 309.

${ }^{33}$ A quotation from B. Karmal's speech in the HES, 27.07.1362AP / 19.10.1983, no. 648, p. 6.

34 On ideological education see e.g.: Kar dar miyan-e tudaha-ra gostaresh midehad [Work among the masses widens], "HES" 22.07.1361AP / 14.10.1982, no. 347, p. 3. 
the observer to find the hidden message by giving him/her some intertextual tips. Intertextuality is a crucial feature of socialist realism that changes the ideology presented in speeches or slogans into communicable messages ${ }^{35}$. On this score one can look for similar slogans in other mass media like the HES to find, for example: Hezb va mardom ba ham-and! Hezb ba poshtibaniye tudeha va tudeha ba pashtibani-ye hezb nirumand-and "The party and the people are together! The party with the masses" support and the masses with the party's support are strong' in a tree-page article on B. Karmal's visit paid to the workers of the Kabul house plant ${ }^{36}$, or Hezb va mardom ba hamand! Rafiq Babrak Karmal dar miyan-e shahriyan-e Kabol "The party and the people are together! Comrade Babrak Karmal among the Kabul residents" in a one-page text on B. Karmal's amicable walk and talks to passers-by on the streets of the capital city ${ }^{37}$. One can also mention here a non-regular column entitled Hezb, mardom va qavva-ye mosallah ba ham-and "The party, the people and the armed forces are together!" which published various texts dedicated mostly to the National Army, solders and their courage as well as their letters to the readers of the $H E S^{3}$.

35 Socialist realism forces the observer to interpret the content by viewing it in the light of its connection with other communications and so it has seemingly little to do with reality and more with its mythologisation (H. Gyunter, Totalitarnoye gosudarstvo kak sintez iskusstv [in:] Socrealisticheskiy kanon, eds. H. Gyunter, E. Dobrenko, Sankt-Peterburg 2000, p. 10; V. Gusev, Gde falsh i gde istina [in:] Agitacyya za schaste. Sovetskoye iskusstvo stalinskoy epohi, ed. H. Gassner, Sankt-Peterburg-Djusseldorf-Bremen 1994, pp. 14-19; E. Dobrenko, Socrealisticheskiy realizm i realnyy socyalizm (Sovetskiye estetika i kritika i proizvodstvo realnosti), "Colloquia" 2007, no. 18, pp. 57-91).

${ }^{36}$ Dar miyan-e kargaran-e pishtaz-e khanasazi [Among the avant-garde workers of the construction establishment], "HES" 24.01.1362AP / 13.04.1983, no. 498, pp. 1-3.

${ }^{37}$ Rafiq Babrak Karmal dar miyan-e shahriyan-e Kabol [Comrade Babrak Karmal among the citizens of Kabul], “HES” 09.07.1362AP / 01.10.1983, no. 633, pp. 1-2.

${ }^{38}$ E.g.: Sarbazan-e ma hamasa mi-afarinand [Our solders compose an epic], "HES” 03.02.1360AP / 23.04.1981, no. 101, p. 2; Sarbazan va afsaran-e qahreman-e ma dar khedmat-e enqelab [Our brave soldiers and officers in the service of the revolution], "HES" 15.10.1360AP / 05.01.1982, no. 207, p. 2 [on solders' fights in the Nangarhar Province]; Chehraha sokhan miguyand [Faces are talking], "HES" 29.10.1360AP / 19.01.1982, no. 213, p. 2 [profiles of a few ordinary solders]; Tekiya ba niru-ye tudaha [Reliance on mass forces], "HES" 20.11.1360AP / 09.02.1982, no. 222, p. 2 [on popular support]; Ba qavva-ye mosallah dar rah-e ta'min-e amniyat [Towards security together with military forces], "HES" 27.11.136oAP / 16.02.1982, n. 225, p. 2; Qavvaye mosallah, madrase-ye jangavaran-e enqelab [Military service - the warrior's school], "HES" 27.11.136oAP / 16.02.1982, n. 225, p. 2 [on the ideological foundations of the civil war]; Naqshe qavva-ye mosallah dar kar-e edame-ye eslahat-e demurkatik-e arzi [The role of military forces in the continuation of land reforms], "HES" 11.12.136oAP / 02.03.1982, no. 231, p. 2; Hamkari- 
The unity, cooperation and leading role of the PDPA is also present in the second, visually smaller but equally important slogan Barname-ye hezbra amali minama'im "We fulfil the programme of the party in practice", where the adjective amali "in practice" projects the proletarian, work-oriented nature of the regime and non-academic realisation of the programme compiled by the party. The sentence "We fulfil the programme of the party in practice" is a metaphorical reply to the rallying cry "The party and the people are together" and also appears in such an appeal as Feysalaha-ye pelinum-ra amali sazim "Let's fulfil the resolutions of the [PDPA's] plenum" to be found in the HES; once again emphasis was placed on action. Interestingly, the last example is complemented by a small graphic in which a crowd of identical people follow the very first figure who is considerably bigger, raising his hand in a tightened fist. His raised hand is also the pole of the PDPA banner:

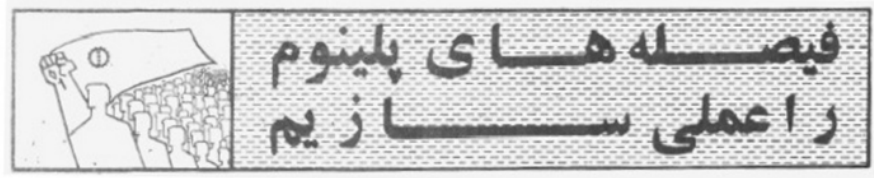

Fig. 3: HES 27.08.1367AP / 17.11.1988, no. 2219, p. 1.

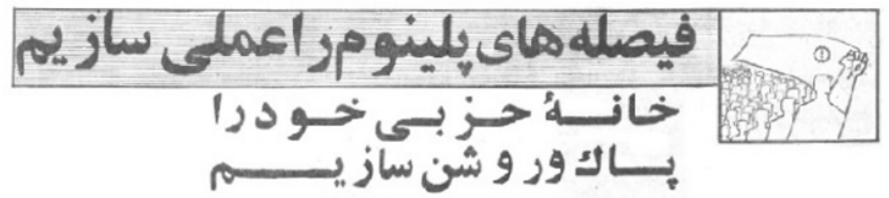

Fig. 4: HES 20.08.1367AP / 10.11.1988, no. 2213, p. 1. The subheading appeal Khane-ye hezbi-ye khod-ra pak va roushan sazim "Let's clean and illuminate our party home" refers to political and ideological reforms carried out after the last Soviet troops left Afghanistan.

Next to a message of linguistic substance R. Barthes distinguished between two iconic categories - one coded and the other non-coded. Since both are of the same pictorial nature they cannot be separated from each other ${ }^{39}$.

ye qavva-ye mosallah ba mardom [Military forces and the cooperation of the people], "HES" 28.11.1361AP / 17.02.1983, no. 452, p. 6; Ta akharin lahza khahim razmid [We will fight to the end], "HES" 24.03.1363AP / 13.06.1984, no. 857, p. 6.

${ }^{39}$ R. Barthes, op. cit., p 36. 
In the case of the analysed Soviet-style poster those who pause in front of it can see three figures - the worker, peasant and solder. Those who have any previous knowledge regarding the Marxism-Leninism can simultaneously read the ideology submerged behind various graphic elements forming the whole composition. The central position is occupied by a worker holding a hammer. He is closer to the bystander than the two other characters of this pictorial story who stand behind him - on the right-hand side a peasant holding a spade, on the left a solder holding a rifle. All three stand upright, keenly eyeing the observer. No-one smiles but we cannot talk about any lack of friendliness. Their faces express clearly a mixture of concentration, dignity or solemnity of a happening that takes place behind them. Their collectedness should influence us-observers coming to a conclusion that they are waiting at this moment for or listening to orders delivered by representatives of the party. Two graphic elements substitute their willingness to cooperate: firstly, the slogan Barname-ye hezb-ra amali minama'im and, secondly, their tools a hammer, spade and rifle. Behind them one can see a crowd of people extending far beyond the composition, maybe one of the marches organised during the International Workers' Day (1st May) or the anniversaries of the Saur Revolution (27th April). Such a mass of people must consist of men and women, workers, peasants, solders, teachers, journalists, academics, clergymen, urban and tribal elites, etc. It is of course impossible to distinguish all the social groups in the poster, but the desired collective character of the Afghan would-be Leninist regime allows us to assume that in the official rhetoric all of them are present as the crowd and in the innumerable flags representing the PDPA (the biggest) and its umbrella organisations - e.g. the National Fatherland Front, the Democratic Youth Organisation of Afghanistan, the Democratic Organisation of Afghan Women, the Democratic Organisation of Afghan Scouts or the Union of Journalists - that fly proudly in the wind. The reference to the mass of people and various organisations emphasises the unity, cooperation and leading role of the PDAP that results from its alliance with all the different social groups:

The government of the Democratic Republic of Afghanistan consists of the political authority of the workers, peasants and other working classes as well as the national and democratic forces of the country that came into being thanks to the will, cooperation 
and support of all the working classes and true compatriots of our dear homeland - Afghanistan ${ }^{40}$.

Little wonder that the PDPA, as an organisation of would-be socialist roots, appears in the press graphic presented below not only as the simple togetherness of people sharing common political targets but first of all as a leading force able to draw their society into fulfilling its own ideological programme:

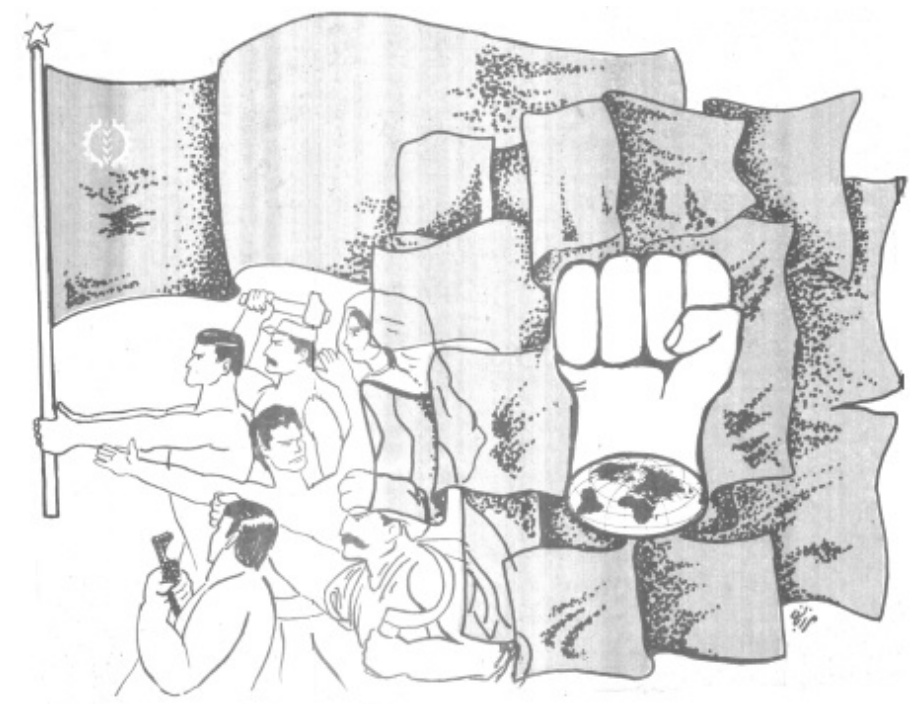

Fig. 5: HES 01.10.1360AP / 22.12.1981, no. 205, p. 1. The illustration accompanies a series articles published on the 18th anniversary of the establishing the PDPA called officially "[the] party of martyrs and heroes".

This graphic makes readers of the HES aware of the PDPA's ideological nature as well as its political goals. A man, most likely a toiler and one of a group formed by workers of indeterminate age, peasants, solders and women, holds the banner on which the PDPA's emblem - a single ear of wheat enclosed by a cog - can be clearly seen. The entire composition also articulates

${ }^{40}$ B. Karmal, op. cit., p. 309. See also e.g.: Ma hama bayad dast ba dast-e ham be-dehim [We should shake hands together], "HES" 29.10.1360AP / 19.01.1982, no. 213, p. 1; Rah-e hezb, rah-e nejat-e zahmatkashan [The party - the proletarians's protection], "HES" 04.12.1360AP / 23.02.1982, no. 228, p. 1; Poshtibani-ye mardom az hezb va davlat [The people's support for the party and the government], "HES" 10.01.1361AP / 30.03.1982, no. 244, p. 1. 
a set of beliefs regarding the bonds between the party and the masses constituting a combined political, cultural, economic and military proletarian might. Its artistic visualisation is represented by a clenched fist, while the globe symbolises the internationality of the Afghan proletarian movement ${ }^{41}$. All the figures, being participants-and-contributors of a dialogue held by the party and the masses, move along in the same direction and, apart from one person, look towards the same point; apparently their march, even if slow, is unremitting: "[the] progress of the revolution in Afghanistan is irreversible" 42 . The only man who looks back shows indicates the way ahead with his right hand and, waving at those who, by implication, lag behind, jollies them along to join the whole group according to the popular rallying cry Workers of the world, unite!, although no-where in the analysed Afghan press could its Dari version - poroletarha-ye jahan muttahid shavid - be found! ${ }^{43}$. His gesture can be also understood as an invitation to enrol in the PDPA made up originally of students, teachers and disappointed bureaucrats only later affiliating a small number of new member classified as workers and peasants ${ }^{44}$. It implies also voluntary participation of the citizens but the whole graphic forges the reality as it does not mention the pressure exerted on government employees to accept party cards:

The distribution of the party cards (...) that starts today is an important moment in the history of our party. This serious political event is a powerful representative of the PDPA and its organisational strength ${ }^{45}$.

${ }^{4}$ On the internationalism: B. Karmal, Kargaran-e Afqanestan! Ba hezb-etan, Hezb-e Demukratik-e Khalq-e Afqanestan peyvandid! [ Workers of Afghanistan! foin your party - the People's Democratic Party of Afghanistan] [in:] B. Karmal, Dar rah-e tahkim-e hakmiyat-e khalq. Majmu'e-ye bayahiyaha wa neveshtaha (1358-1359) [Towards the strengthening of mass leadership. Collection of speeches and texts (1358-1359)], Kabol 1362AP/1983-4, pp. $135 \mathrm{ff}$.

${ }^{42}$ B. Karmal, Zenda bad..., p. 410.

${ }^{43}$ I only found it on one photography taken by S. Soboloev in 1979 in Kabul and re-printed in L. Gerber, The Taliban in Afghanistan, New York 2011, p. 11.

${ }^{44}$ B. R. Rubin, The Fragmentation of Afghanistan. State Formation and Collapse in the International System, New Haven-London 1995, p. 128. H. S. Bradsher called Afghan revolutionaries ironically "teashop ones" (H. S. Bradsher, Afghanistan and the Soviet Union, Durham 1983, p. 91).

45 B. Karmal, Kart-e ozviyyat-e Hezb-e Demukratik-e Khalq-e Afqanestan-ra chun sharaf-e khod hefz mikonam va an-ra vahdat-e khadashe-ye napazir-e hezb-e qahreman-e khod midanam [I protect my cart of the People's Democratic Party of Afghanistan like my own honour and consider it as the impregnable unity of the heroes' party] [in:] B. Karmal, Tahkim-e hezb va 
Having said all this, one question arises: does the observer understand the message conveyed by the (non)iconic elements of the poster? Or maybe such a composition transcends readability due to its socialist realistic nature? To stay in power, the authorities must use phraseology that is clear for the audience so the form of persuasion should be constructed collectively by manipulative practitioners. Those who are aware of Marxist-Leninist ideology can more or less read the poster presented above. Those who are not will not read it properly just as in the case of L. Wittgenstein's language-games indicating that each action can be understood only because the participants in the game have a priori knowledge regarding its rules. To learn the rules one needs to be constantly surrounded by the object in the same way that persuasion is more effective than compulsion because " $[t]$ he transmutative power of propaganda derives its energy from the permanent need of a man to be perpetually enchanted with the world" ${ }^{46}$. In the case of Afghanistan, access to such ideological posters, press or poetry was limited by the civil war to major cities. Consequently, they did fall on deaf ears and despite all their efforts, the PDPA was not able to broaden its social basis and to defeat the counter-revolutionaries.

All the observations presented above are intended to simulate further, more complex research on the subject and will, hopefully, allow two unsolved questions to be answered:

(1) Changes in rhetoric used before and after 1978 as well as the possible influence of the Soviet and Iranian communists' phraseology;

(2) The culturally-dependant conceptualisation of the world into pictures. Afghanistan, belonging to a Sunni zone, lies between two countries where the image plays a significantly semantic role - Iran and Pakistan. Can one speak about Iranian and Pakistani influences with regard to usage of the picture as a means of communication, or not?

peyvand-e an ba khalq. Majmu'e-ye bayaniyaha va neveshtaha (1360-1361) [The strengthening of the party and its relations with the masses. A collection of speeches and texts (1360-1361)], Kabol 1362AP/1983-4, p. 164.

${ }^{46}$ P. Chelkowski, H. Dabashi, op. cit., p. 33. 


\section{Bibliography}

1. 30 so'al va 30 javab dar bare-ye H.D.Kh.A. va siyasat-e an [3o questions and 30 answers about the PDPA and its politics], Kabol 1369AP/ 1990-1.

2. Afganistan, revolucya prodolzhayetsya, M. Baryalay, Moskva 1984.

3. Austin J. L., Mówienie i poznawanie. Rozprawy i wykłady filozoficzne, przeł. B. Chwedeńczuk, Warszawa 1993.

4. Barfield T., Afghanistan. A Cultural and Political History, PrincetonOxford 2010.

5. BARThes R., Rhetoric of the Image [in:] Barthes R., Image - Music - Text, trans. S. Heath, New York 1977, pp. 32-51.

6. BAUER E., Sprachlicher Wandel als Ergebnis politisch motivierter Sprachlenkung: neuere Entwicklungen im Pashto Afghanistans [in:] Proceedings of the Second European Conference of Iranian Studies held in Bamberg, 3oth September to 4 th October 1991, by the Societas Iranologica Europeae, eds. B. G. Fragner et al., Rome 1995, pp. 53-63.

7. Bradsher H. S., Afghanistan and the Soviet Union, Durham 1983.

8. Centuivres P., Centlivres-Demont M., Et si on parlait de l'Afghanistan. Terrains et textes 1964-1980, Paris 1988.

9. Centlivres P., Centrlivres-Demont M., Portraits d'Afghanistan, Paris 2002.

10. Centlivres-Demont M., Popular Art in Afghanistan. Paintings on Trucks, Mosques and Tea-Houses, trans. R. Charleston, Graz 1976.

11. Chelkowski P., Dabashi H., Staging a Revolution: the Art of Persuasion in the Islamic Republic of Iran, New York 1999.

12. Dobrenko E., Socrealisticheskiy realizm i realnyy socyalizm (Soveckiye estetika $i$ kritika $i$ proizvodstvo realnosti), "Colloquia" 2007, no. 18, pp. 57-91.

13. Dudek R., Siembirowicz Z. (ed.), Partia - państwo - społeczeństwo, Warszawa 1978.

14. Dzięgiel L., Pstrusińska J., Rysunkowe echa egzotycznej wojny, "Arcana" 2001, no. 41 (5), pp. 167-172.

15. Elias J. S., Aisha's Cushion. Religious Art, Perception, and Practice in Islam, Cambridge MA-London 2012.

16. Enayat H., Modern Islamic Political Thought, Austin 1982.

17. Gaenszle M., Gengnagel J., Visualizing Space in Banaras. Images, Maps, and the Practice of Representation, Wiesbaden 2006.

18. Gerber L., The Taliban in Afghanistan, New York 2011. 
19. Gyunter H., Totalitarnoye gosudarstvo kak sintez iskusstv, [in:] Socrealisticheskiy kanon, H. Gyunter, E. Dobrenko (red)., Sankt-Peterburg 2000, pp. 7-15.

20. Gusev V., Gde falsh i gde istina [in:] Agitacyya za schaste. Sovetskoye iskusstvo stalinskoy epohi, ed. H. Gassner, Sankt-Peterburg-Djusseldorf-Bremen 1994, pp. 14-19.

21. Hotak bin Davud M., Pata Khazana, Kabol 1339AP/1960-1.

22. КАмРка A., Retoryka jako manifestacja i uprawomocnienie wtadzy [in:] A. Kampka (ed.), Między znaczeniem a działaniem. Retoryka $i$ władza, Warszawa 2012, pp. 19-36.

23. Karmal B., Zenda bad ettehad-e tabaqe-ye kargar, dehqanan va hameye zahmatkashan-e keshvar-e ma! [Viva the unity of the classes of the workers and peasants and all the proletarians of our country!] [in:] Karmal B., Dar rah-e tahkim-e hakmiyat-e khalq. Majmu'e-ye bayahiyaha va neveshtaha (1358-1359) [Towards the strengthening of mass leadership. A collection of speeches and texts (1358-1359)], Kabol 1362AP/1983-4, pp. 408-416.

24. Karmal B., Kart-e ozviyyat-e Hezb-e Demukratik-e Khalq-e Afqanestanra chun sharaf-e khod hefz mikonam wa an-ra vahdat-e khadashe-ye napazir-e hezb-e qahreman-e khod midanam [I protect my cart of the People's Democratic Party of Afghanistan as if it were my own honour and consider it to be the impregnable unity of the heroes' party] [in:] Karmal B., Tahkim-e hezb va peyvand-e an ba khalq. Majmu'e-ye bayaniyaha va neveshtaha (1360-1361) [The strengthening of the party and its relations with the masses. A collection of speeches and texts (13601361)], Kabol 1362AP/1983-4, pp. 163-165.

25. Karmal B., Kargaran-e Afqanestan! Ba hezb-etan, Hezb-e Demukratike Khalq-e Afqanestan peyvandid! [Workers of Afghanistan! Join your party - the People's Democratic Party of Afghanistan] [in:] Karmal B., Dar rah-e tahkim-e hakmiyat-e khalq. Majmu'e-ye bayahiyaha wa neveshtaha (1358-1359) [Towards the strengthening of mass leadership. A collection of speeches and texts (1358-1359)], Kabol 1362AP/1983-4, pp. $144^{-152 .}$

26. Khoshe-ye khorshid. Gozine-ye she'r-e kudak [Rays of sunshine. Selections from poetry for children], Kabol 1363AP/1984-5.

27. KŁagisz M. M., Visual Propaganda in the Democratic Republic of Afghanistan - Preliminary Report, "The Polish Journal of the Arts and Culture" 2015, no. 14 (2), pp. 101-122. 
28. LAYEQ S., Samt-e roushan-e jaddaha [The bright side of the roads], Kabol 1363AP/1984-5.

29. Rasul Amin A., A General Reflection on the Stealthy Sovietisation of Afghanistan, "Central Asian Survey" 1984, no. 3 (1), pp. 47-62.

30. Roy O., The Origins of the Afghan Communist party, "Central Asian Survey" 1988, no. 7 (2-3), pp. 41-58.

31. Rubin B. R., The Fragmentation of Afghanistan. State Formation and Collapse in the International System, New Haven-London 1995.

32. Terrenoire M.-O., Guerre d'Afghanistan - Images de femmes, "Central Asian Survey" 1987, no. 6 (3), pp. 77-102.

33. Vogel M., Roter Teufel - mächtiger muğahid. Widerstandsbilder im sowjetisch-afghanischen Krieg 1979-1989, Wien-Köln-Weimar 2008.

\section{Articles from the "Haqiqat-e Enqelab-e Saur"}

34. A quotation from B. Karmal's speech published in the HES, 27.07.1362 / 19.10.1983, no. 648, p. 6.

35. Amuzesh-e Lenin - mash'al-e rahnama-ye razmandegan-e enqelabi [Lenin's teaching - the guiding torch of revolutionary fighters], 03.02.1360AP / 23.04.1981, no. 101, p. 4.

36. Ba qavva-ye mosallah dar rah-e ta'min-e amniyat [Towards security together with military forces], 27.11.1360AP / 16.02.1982, no. 225, p. 2.

37. Chehraha sokhan miguyand [Faces are talking], 29.10.1360AP / 19.01.1982, no. 213, p. 2.

38. Dar miyan-e kargaran-e pishtaz-e khanasazi [Among the avant-garde workers of the construction establishment], 24.01.1362AP / 13.04.1983, no. 498 , pp. $1-3$.

39. Hamkari-ye qavva-ye mosallah ba mardom [Military forces and the cooperation of the people], 28.11.1361AP / 17.02.1983, no. 452, s. 6.

40. Kar dar miyan-e tudaha-ra gostaresh midehad [Work among the masses widens], 22.07.1361AP / 14.10.1982, no. 347, p. 3.

41. Lenin va Afqanestan [Lenin and Afghanistan], 03.02.1360AP / 23.04.1981, no. 101 , p. 1.

42. Ma hama bayad dast ba dast-e ham be-dehim [We should shake hands together], 29.10.1360AP / 19.01.1982, no. 213, p. 1.

43. Naqsh-e qavva-ye mosallah dar kar-e edame-ye eslahat-e demurkatik-e arzi [Role of military forces in continuation of land reforms], 11.12.136oAP / 02.03.1982, no. 231, p. 2. 
44. Poshtibani-ye mardom az hezb va davlat [The people's support for the party and the government], 10.01.1361 AP / 30.03.1982, no. 244, p. 1.

45. Qavva-ye mosallah, madrase-ye jangavaran-e enqelab [Military service - the warrior's school], 27.11.136oAP / 16.02.1982, n. 225, p. 2.

46. Rafiq Babrak Karmal dar miyan-e shahriyan-e Kabol [Comrade Babrak Karmal among the citizens of Kabul], 09.07.1362 / 01.10.1983, no. 633, pp. 1-2.

47. Rah-e hezb, rah-e nejat-e zahmatkashan [The party - the proletarians's protection], 04.12.1360/23.02.1982, no. 228, p. 1.

48. Sarbazan-e ma hamasa mi-afarinand [Our soldiers compose an epic], 03.02.1360 / 23.04.1981, no. 101, p. 2.

49. Sarbazan va afsaran-e qahreman-e ma dar khedmat-e enqelab [Our brave soldiers and officers in the service of the revolution's], 15.10.1360 / 05.01.1982, no. 207, p. 2.

50. Ta akharin lahza khahim razmid [We will fight to the end], 24.03.1363AP / 13.06.1984, no. 857, p. 6.

51. Tekiya ba niru-ye tudaha [Reliance on mass forces], 20.11.1360AP / 09.02.1982, no. 222, p. 2.

52. Sima-ye Lenin dar ayine-ye zendegi-ye khosusi [Lenin's picture in the reflection of private life], 03.02.1360AP / 23.04.1981, no. 101, p. 4.

53. Zendegi va asar-e Lenin [Lenin's life and works], 03.02.1360AP / 23.04.1981, no. 101, p. 3 . 